\title{
A Study on the Basic Problems of Ideological and Political Teaching Reform in the Major Courses of Universities
}

\author{
Guihai Liu',2*, Xiaohong Liư ${ }^{3}$, Zhenhui Huang1, Fulong Cui', Meixuan Ren1 \\ ${ }^{1}$ College of City Construction, Jiangxi Normal University, Nanchang, China \\ ${ }^{2}$ College of Marxism, Jiangxi Normal University, Nanchang, China \\ ${ }^{3}$ Student Office of Nanchang Institute of Technology, Nanchang, China \\ Email: ${ }^{*}$ liuguihai@jxnu.edu.cn
}

How to cite this paper: Liu, G. H., Liu, X. H., Huang, Z. H., Cui, F. L., \& Ren, M. X. (2019). A Study on the Basic Problems of Ideological and Political Teaching Reform in the Major Courses of Universities. Creative Education, 10, 3420-3432. https://doi.org/10.4236/ce.2019.1013264

Received: December 2, 2019

Accepted: December 20, 2019

Published: December 23, 2019

Copyright $\odot 2019$ by author(s) and Scientific Research Publishing Inc. This work is licensed under the Creative Commons Attribution International License (CC BY 4.0).

http://creativecommons.org/licenses/by/4.0/

\begin{abstract}
The new curriculum plan of ideological and political course in university is not only based on the practical needs of ideological education in colleges in the new era, but also based on the urgent requirements of the fundamental task of moral education in universities. It is also an important achievement in the process of long-term exploration of ideological and political theory education in colleges. In principle, the reform of ideological and political teaching of specialized courses in universities should be student-oriented and practice-oriented; in terms of the goal, we should push the reform towards standardization from two levels: the fundamental goal and the specific goal. The key point of reform is to excavate and refine the elements of ideological and political education in specialized courses, and the timing and links of the integration of ideological and political education elements in specialized courses. Therefore, the evaluation standard and method of ideological and political teaching reform in universities should focus on students and teachers to construct a "three-dimensional and four-body" evaluation system of ideological and political teaching, and at the same time follow scientific and reasonable evaluation principles, thus ideological and political education and professional teaching in the same direction.
\end{abstract}

\section{Keywords}

Colleges, Professional Courses Ideological and Political, Teaching Reform, The Basic Problem

\section{Introduction}

In December 2016, at the national conference on ideological and political work 
in colleges, $\mathrm{Xi}$ Jinping, General Secretary of the CPC Central Committee, pointed out that the central link should be to cultivate people through virtue, run ideological and political work through the whole process of education and teaching, and realize the whole process of educating people all-round education (Xi, 2016). In February 2017, Opinions on strengthening and improving ideological and political work in universities under the new situation put forward by the CPC central committee and the state council clearly put forward that ideological value should be guided throughout the whole process and every link of education and teaching, and then form a long-term mechanism of teaching, scientific education, social practice education, management education, service-based education, culture education, organize education. It is also emphasized that we should strengthen the construction and management of classroom teaching and various ideological and cultural positions, fully explore and use the ideological and political education resources contained in various disciplines, and improve the management methods of classroom teaching in colleges (The Central Committee of the CPC and the State Council, 2017). Ideological and political education is the lifeline of all work in colleges. It is an important measure to enhance the ideological and political education ability of colleges and protect the lifeline of colleges to give full play to the ideological and political education function of specialized courses in colleges, while strengthening and improving the education and teaching of ideological and political theory courses, and then form the ideological and political education community.

\section{The Background of the Ideological and Political Education Reform of Specialized Courses in Colleges}

From the perspective of reality, the function of ideological and political teaching reform of specialized courses in colleges to realize collaborative education is proposed in view of the effectiveness of ideological and political theory courses; Fundamentally speaking, there are not only the complexity of ideological work in the new era, but also the urgent need of the fundamental task of establishing morality and cultivating people in colleges. At the same time, it is also an important achievement in the process of strengthening and improving the ideological and political theory course.

\subsection{The Need of Strengthening Ideological Work in Colleges in the New Era}

Colleges are important places for ideological education, and curriculum is an important carrier of ideological education. Therefore, it is necessary to establish the system of ideas and beliefs related to social activity or political planning through curriculum (Yu, 1993). On the one hand, it is necessary to create a benign environment conducive to the generation of mainstream ideological ideas in various courses of colleges, and apply correct ideological guidance to them, so as to continuously establish the way of thinking and values of emotional selec- 
tion tending to mainstream ideology among students, and lay a solid foundation for the formation of correct beliefs and beliefs among students. On the other hand, all kinds of college courses need to work together to promote the formation of subject ideology, and through the joint effect of various courses to stimulate students' cognitive decision-making, emotional motivation, willpower training, concept generation, faith and other links of the benign operation, which enables students to self-integrate and internalize all kinds of ideological information in the outside world so as to form a mainstream ideological system with relative stability and as a prerequisite for practical activities. From the perspective of the practical operation of education, whether the ideological work can be effectively carried out in colleges mainly depends on the administrators and teachers of specialized courses, but it is a pity that the two are not fully engaged in ideological work. According to the survey results of a college in China, a considerable number of professional teachers only focus on their major and class, regardless of thoughts and extracurricular. "According To Statistics, 72.7\% of the teachers of specialized courses are only engaged in the teaching of specialized courses, as many as 86.8 percent of teachers of specialized courses think that students' ideological and political education is beyond their responsibility. However, only 28.1 of the teachers of specialized courses have the content of ideological and political education infiltrated into the teaching of specialized courses." (Mo, 2010) It can be seen that speeding up the ideological and political teaching reform of specialized courses in colleges is the realistic need to strengthen the ideological work of colleges in our country in the new era.

\subsection{Colleges Should Fulfill the Basic Task of "Cultivating People by Virtue"}

The foundation of a university is to cultivate people by virtue. Only by paying attention to students, caring for students and serving students, enlightening students' thoughts and nourishing their culture in the process of preaching, teaching and solving problems, can we cultivate qualified students with both ability and moral integrity and all-round development. The completion of this task is closely related to the comprehensive and systematic educational achievements of various publicity activities organized by each teaching course, and even to the educational background of the living environment and social experience of the educational objects as well as the influence of their ideas. Therefore, it is far from enough to only rely on one dimension of ideological and political theory course to complete the fundamental task of cultivating people through virtue, we should take the cultivation of morality as the central link, run ideological and political work through the whole process of education and teaching, and realize the whole process of educating people in an all-round way (Commentator of Xinhua News Agency, 2016), construct a concentric circle of lide's cultivation of people, which is centered on the course teaching, especially the ideological and political courses, on the extension layer of daily ideological and political work in colleges, and on the extension layer of good social ecology and positive concept influence. 
In this concentric circle, curriculum teaching plays a core and key role. Whether ideological and political theory courses and specialized courses can be in the same direction basically determines the achievement of the fundamental task of moral education in colleges, so the two must be coordinated to produce a superposition effect. Therefore, cultivating qualified talents who can undertake the important task of building socialism with Chinese characteristics and the great task of national rejuvenation can fulfill the fundamental task of establishing morality and cultivating people in colleges. It is necessary to construct a new education system with ideological and political theory course as the core and ideological and political course as the extension layer.

\subsection{The Latest Achievement of Ideological and Political Education in Colleges}

General Secretary Xi pointed out that: "All classes have the function of educating people, and ideological and political work should not be treated only as ideological and political courses", "We should make good use of the main channel of classroom teaching", "Other courses should keep a good section of the 'canal' to plant good responsibility 'field"' (Xi, 2016). The new concept of guarding channels and planting fields clarifies the main responsibility and historical mission of other specialized courses in ideological and political education. We should thoroughly explore the thoughts of ideological and political education resources of various specialized courses, take basic task of comprehensively deepen the reform of curriculum and teaching and ensure that colleges cultivate people through virtue as an important strategy of education, construct the ideological and political education curriculum system in colleges as a whole, lay out the function orientation and construction path that ideological and political theory courses and other specialized courses should undertake in the process of ideological and political education for college students, so as to realize the collaborative education of other specialized courses and ideological and political theory courses. Because the current ideological and political courses in colleges to answer the question of what kind of people to train and how to train people and for whom to train people is difficult to adapt to the needs of ideological and political work in colleges under the new situation, it is a good choice to explore other ways and solutions to solve these problems. In order to give full play to its educational function, colleges not only need ideological and political theory courses to play a key and core role, but also need to give play to the role of other kinds of professional courses, so that other kinds of professional courses and ideological and political theory courses can complement each other and jointly create a larger pattern of higher education.

\section{The Basic Principle and Goal of Ideological and Political Education Reform of Specialized Courses in Colleges}

The teaching reform of integrating specialized courses in colleges should not 
only follow the basic principles of ideological and political education, but also adhere to the principle of imperceptible salt dissolving in soup. At the same time, it is necessary to realize the educational goal of ideological and political education in colleges, which has an important impact on students in both the fundamental goal and the specific goal.

\subsection{The Basic Principles to Be Followed in the Reform of Ideological and Political Education in Specialized Courses}

\subsubsection{The Principle of "Salt Dissolving in Soup"}

The ideological and political education in colleges in the new era is faced with a highly complex environment, the subject and object of education as well as the content and methods of education have undergone new changes. It is difficult to adapt to the development of ideological and political education to rely solely on ideological and political courses. Therefore, we should adhere to the principle of salt dissolving in soup, instill ideological and political education resources while imparting professional knowledge, so that students can receive correct education of Marxism and socialism with Chinese characteristics imperceptibly in the process of professional learning. As secretary Xi-Jin-ping pointed out: good ideological and political work should be like eating salt, but you can't just eat salt, the best way is to dissolve it in a variety of foods and absorb it naturally. Only when the teachers of each specialized course have a deep understanding of the nature of education and the ultimate purpose of education, fully realize the invisible educational resources of each course, and establish a benign symbiotic conjugation and resonance mechanism, can the ideological and political education community effectively operate and fully realize the "common effect" (He, 2017).

\subsubsection{Principle of Subjectivity}

To run the ideological and political work in colleges well is an important measure to solve the fundamental problem of what people to train, how to train people and for whom to train people. Fundamentally speaking, it is the job of being a person. Only by focusing on students, caring for students, serving students, solving doubts and solving doubts, and building consensus, can we continuously enlightening students with thoughts and culture, so as to cultivate talents with all-round development of morality and ability. Therefore, it is necessary to establish the principal position of students in the reform of ideological and political education of professional courses and realize the transformation of students from passive listening to lectures to active participation; By abandoning the traditional indoctrination teaching method, the ideological and political education of specialized courses is transformed from simple memory to active construction by students; through the integration and expansion of teaching resources and the introduction of social practice, the ideological and political education of specialized courses can be transformed from theoretical learning to the cultivation and practice of socialist core values; through the scientific innovation of assessment methods, the transformation of ideological and political education 
in professional courses from exam-oriented to the comprehensive development of students' ideological and moral quality and practical innovation ability is realized (Yang, 2017).

\subsubsection{Principle of Practicality}

Correct world outlook, outlook on life and values come from both theoretical learning and practical knowledge acquired through social life. Ideological and political education of specialized courses in colleges should not only be limited to the field of classroom and campus, but also gradually extend to other fields of social life. So professional class teacher can add specialized course in teaching design ideological education practice, including volunteer, go out to visit, social investigation and share a series of activities such as reading, let the students participate in social practice activities in the process of personally to carry out the course ideological education content, when to solve social practical problems to practice professional class education concept of education, in social life to be able to consciously practice the socialist core values, Let the ideological and political education of specialized courses in colleges truly enter into the hearts of the majority of students, gradually transition from the subject learning of professional theoretical courses to the emotional experience of professional practice activities, and finally internalize the learning results in specific social practice activities, so as to realize the unity of ideological and political education theory, emotion and behavior of specialized courses.

\subsection{The Educational Goal to Be Realized in the Reform of Ideological and Political Education in Specialized Courses}

The purpose and task of ideological and political education in colleges reflect the essence and direction of ideological and political education and stipulate the basic content of ideological and political education (Chen \& Zhang, 2016). Therefore, it is the basic premise to carry out the ideological and political education reform of specialized courses in colleges smoothly and achieve obvious results to clarify the educational goal to be achieved in the ideological and political education of specialized courses in colleges. The goal of ideological and political education of specialized courses in colleges is not single, but a goal system, which can be divided into different categories and levels.

\subsubsection{Fundamental Goal}

The fundamental goal of ideological and political education in colleges refers to the ultimate goal of ideological and political education activities, which is the highest goal of ideological and political education (Chen \& Zhang, 2016). Ideological and political education in our country takes communism as direction. Directly acting on people's ideological character is the cultivation of people's ideological and moral quality activities. This nature defines the fundamental educational goal of the form of ideological and political education in specialized courses in China, which is to improve students ideological and moral quality, 
promote the free and comprehensive development of human beings, and motivate students to strive for the construction of socialism with Chinese characteristics and the eventual realization of communism through ideological and political education in specialized courses.

\subsubsection{Specific Goals}

The specific goal of ideological and political education is the expected goal of each specific activity of ideological and political education. The specific goal of ideological and political education in college specialized courses is the embodiment of the fundamental goal. Because the fundamental goal of ideological and political education is unitary, but the specific goal is pluralistic, for example, it can be decomposed into knowledge transmission, emotion construction and ability cultivation. Moreover, the specific goals of college specialized courses will change with the changes of times, which is historic.

\section{The Main Content of Ideological and Political Teaching Reform of College Specialized Courses}

On the one hand, the ideological and political education reform of specialized courses in colleges requires specialized course teachers to fully explore and refine the ideological and political education elements contained in specialized courses due to the difference between specialized ideological and political theory courses and ready-made textbooks and teaching materials. On the other hand, in order to achieve the organic unity of "teaching" and "education" and organically integrate ideological and political content with professional knowledge, it is necessary to express the "ideological and political taste" of specialized courses, solve the problems of timing and links of integrating ideological and political education elements of specialized courses, and avoid the appearance of two students.

\subsection{The Excavation and Refinement of Ideological and Political Education Elements in Specialized Courses}

The exploration of elements of ideological and political education in specialized courses and the extraction of problems are the foundation and key work of the teaching reform of "curriculum ideological and political education" (Cheng, 2018). To judge whether the teachers of specialized courses have-fully tapped the ideological and political education resources contained in the courses they teach, the degree of digging should be used instead of the amount of digging. However, the mining degree of ideological and political education resources of specialized courses depends on a variety of factors. The following measures can be taken to do a good job in mining and refining:

Firstly, to fully understand the differences and characteristics of different types of courses, specific analysis of physical problems, find the focus of mining. Considering the different contents of "ideological and political education elements" in different courses, in order to achieve twice the result with half the effort, mining should be carried out in an orderly way. In comparison, the educa- 
tion of philosophy and social science curriculum education resources is significantly higher than the amount of natural science course learning general secretary said: "the philosophy and social sciences in colleges have important educational function, facing all students, help students form the correct world outlook outlook on life, values, and improve the moral cultivation and spiritual realm, the scientific thinking habit, bit, promote the healthy development of body and mind and personality." (Xi, 2017) In addition, different subjects and courses have different contents of "ideological and political education elements", and different courses have different emphases of ideological and political education resources. For example, science and engineering courses mainly contain scientific spirit, patriotism and professional ethics.

Secondly, it needs the close cooperation between ideological and political theory teachers and professional teachers. Because of the development of ideological and political education of specialized courses, we need to focus on improving the ideological and political quality and ideological and political ability of specialized course teachers. However, the reality is that teachers of specialized courses "only care about the major, not thinking", and it is even difficult to accurately grasp the ideological and political education resources contained in specialized courses. Therefore, in order to better identify and explore the "ideological and political education elements" of specialized courses, the teachers of specialized courses need guidance and help from the teachers of ideological and political theory courses while improving their ideological and political literacy and ideological and political ability. Colleges should set up a platform to facilitate the cooperation between the two types of teachers, innovate the management system and mechanism, and encourage various forms of cooperation, such as group discussion for preparing lessons, holding special discussions, co-writing papers and applying for topics.

Thirdly, it is to strengthen the top-level design and realize the systematic exploration of ideological and political education elements with the cooperation of multiple courses. The exploration of "ideological and political education elements" in specialized courses can take the form of individual courses. Multiple courses can also be coordinated and systematically advanced. However, we should advocate the method of collaborative operation and systematic mining: with the professional training program as the carrier, first determine the overall training objectives and mining requirements of the professional level, then decompose the objectives and requirements into the course group, and finally subdivide them into each course.

Fourthly, it is necessary to realize that the excavation of "ideological and political education elements" in specialized courses is not a one-time project.

On the other hand, with the deepening of digging and refining, the teachers of specialized courses will continuously improve their understanding and find out the important elements of ideological and political education that have not been recognized before to supplement them: On the other hand, the content of ideo- 
logical and political education itself is also dynamic. With the development of The Times and the advancement of the great cause of socialism with Chinese characteristics, new ideas, new ideas, new judgments, new theories and new strategies will constantly form and emerge, and turn into the indispensable content of ideological and political education in colleges.

\subsection{The Timing and Links of Integrating the Elements of Ideological and Political Education in Specialized Courses}

Baosheng Chen, minister of education, pointed out: "we should carefully study the way of integrating the theoretical innovation results of the party with the professional theoretical knowledge of various disciplines. We can neither make 'pizza' nor make 'Sandwich', 'rou jia mo', to do 'Buddha jumping over the wall', 'Braised vegetables', really put Xi Jin-ping thought on socialism with Chinese characteristics for a new era into the teaching materials." (Yi \& Huang, 2018) Therefore, if the specialized course teachers simply in order to be able to; speak out "education", Shouting there, with some professional irrelevant content into the classroom, not education effect, not only could make matters worse, even counterproductive, breeding ground for students of ideological education of resentment, but also will damage the specialized course teaching effect. To this end, efforts should be made in the following aspects:

The first one is to find the correspondence of ideological content and professional knowledge, through the systematic course design, in the form of seamless docking and organic integration, establish a generative interactive relationship, do "gene type, fusion, follow the" education "professional" the principle of teaching is learning, clear breakthrough point of every ideological elements in professional course, clarify the relationship between ideological elements with professional content, accomplish know fairly well, there are telltale signs.

Second, it is ideological education elements into special vision theory and method should be based on science, taking pieces, the strategy of "key" to highlight, the word deep" fluctuation Kong-Fu, achieve the depth of fusion.

Third, is to integrate the elements of ideological and political education. Students should focus on vivid practical problems, take the classroom as the main position, and make the best use of the situation to encourage students to do extended study or research individually or in teams. Because problems are the voice of The Times, the people are the biggest political, seize the problem to seize the people. As long as students are guided to think and explore the hot issues in the national economy and people's livelihood in combination with their major, they can achieve the "ideological and political" and professional growth, and achieve the ideological and political education effect of twice the result with half the effort.

\section{Evaluation Standards for Ideological and Political Teaching Reform of College Specialized Courses and the Principle}

The main body of the reform of ideological and political teaching in college spe- 
cialized courses is students and teachers. Therefore, the evaluation or evaluation of the actual effect of the reform of ideological and political teaching in specialized courses should also focus on these two subjects, so as to prevent the formal and empty teaching of "ideological and political teaching in specialized courses".

\subsection{To Construct the Evaluation System of Ideological and Political Teaching Reform of "Three-Dimensional Four-Body" Specialized Courses}

Because of the ideological and political education of the compound, osmosis, it is difficult to ascribe the development of the students to the ideological and political literacy comes down to specific work effect, but this does not mean that it cannot be evaluated, because every course has its specific ideological and political education, mainly including the three dimensions of emotion, attitude and values. The improvement of students' ideological and political literacy is the superposition effect of the work of ideological and political theory teachers, specialized course teachers, university counselors and academic tutors. Therefore, the evaluation of ideological and political teaching reform in colleges can be carried out from three dimensions of emotion, attitude and values, as well as four main bodies of ideological and political theory teachers, specialized course teachers, college counselors and academic tutors, so as to guarantee the objective, comprehensive and scientific evaluation results.

First of all, the dimension of evaluation should be around emotion, attitude and value. Because any course has its specific ideological and political education appeal, mainly including emotion, attitudes, values three dimensions. For example, when evaluating students' emotion, it can be divided into learning initiative, curriculum confidence, willingness to cooperate and communicate, and subject belonging. In the evaluation of student values, it can be subdivided into worldview, outlook on life and values.

Secondly, the subject of evaluation should include teachers of ideological and political theory, teachers of specialized courses, university counselors and academic tutors. The contents and related standards of educating students set by ideological and political education of specialized courses are evaluated independently by each subject and a comprehensive evaluation is formed on the basis of consultation. However, in the process of implementation, it is also necessary to lay emphasis on different evaluation subjects and reflect different evaluation perspectives. Among them, the teachers of specialized courses mainly evaluate the changes of students' emotions, attitudes and values in the study of discipline, their loyalty to the discipline, their recognition of the professional value of the discipline and their ethics in the discipline. College counselors should pay more attention to the change of students' academic behavior and their participation in professional activities. Academic tutors focus on evaluating students' academic ideal, academic value and future career choice. However, ideological and political theory teachers should pay more attention to the evaluation of socialist core values on the guidance of students' professional thoughts. 
Finally, the evaluation standard of "three dimensional four body" should follow the systematic principle. No matter according to which dimension, by which main body carries on the appraisal, all needs to carry on the appraisal activity systematically, finally forms the comprehensive appraisal. Because the student course education theory accomplishment of ascension is a gradual process, "process evaluation, qualitative evaluation, evaluation is three principles of the curriculum education evaluation." (Lu, 2018), therefore more attention in the process of evaluating qualitative rather than quantitative evaluation, and should not only pay attention to process the results more theory, pay more attention to descriptive evaluation rather than distinct evaluation, pay more attention to students longitudinally and self-development.

\subsection{The Evaluation Principle of Ideological and Political Teaching Reform of Professional Courses}

In addition to the general principles, the teaching evaluation of "course ideology and politics" should also follow the following principles:

Firstly, it is apolitically correct and clear-cut principle. This is the first principle of performance appraisal of "course ideology and politics". General secretary Xi-Jin-ping stressed: "The key to running a good ideological and political theory course is to put teachers first. We should be strong in politics, let those who have faith speak their faith, be good at looking at problems politically, and keep clear in the face of great rights and wrongs." (Xi, 2019) This requires professional class teacher always exalted banner of Marxism, to promote the newest theoretical results which Marxism in Xi-Jin-ping new era the ideas of socialism with Chinese characteristics, carrying forward and practicing the socialist core values, resolutely put an end to the major policies against the party and state, unconstitutional law, endangering national security speech.

Secondly, we should follow the principle of self-cultivation. Professional "course ideological and political" not only has the function of cultivating and guiding students, but also has the function of self-education and self-perfection for professional course teachers. On the one hand, "professional course ideological politics" means that professional course teachers train and educate students through the teaching of relevant courses. On the other hand, it is also a process of self-education for professional teachers. Therefore, teaching evaluation should not only pay attention to the influence of "curriculum ideological and political education" on students, but also on teachers, and pay more attention to the improvement of teachers' political position, teachers' Ideological and political quality and professional ethics (Cheng \& Wang, 2019).

Thirdly, the principle of "ideological and political" specialty teaching and learning. This mainly includes two points: first, in the specialized course teaching "ideological and political" content must not be missing, this is the most basic requirement; Second, there should be no double skin. How to integrate the party's theoretical innovation results with the theoretical knowledge of various dis- 
ciplines is the key to the success or failure of the major "course ideological and political". Therefore, it is necessary for teachers of specialized courses to avoid blindly copying and talking about things in various ways. They should choose ways in line with "ideological and political thinking" and "professional and mutual growth" so as to achieve the educating effect of "sneaking into the night with the wind and moistening things silently". The construction and application of engineering management teaching platform play an important role in improving the quality of practical teaching and cultivating high-quality engineering management professionals (Liu et al., 2018).

Finally, the principle of combining self-assessment with other assessment. Self-evaluation includes teachers' self-evaluation and students' self-evaluation. Self-evaluation of teachers refers to the evaluation of teachers on their own "course ideological and political", which is a process of self-diagnosis, self-adjustment and self-improvement of teachers, and is conducive to stimulating and promoting teachers of specialized courses to summarize experience, find problems and improve their ideological and political teaching level. Student self-education refers to students' self-evaluation of whether the major "course ideological and political" has a positive impact on him and the size of the impact. His evaluation includes teachers' evaluation of students and students' evaluation of teachers, but the emphasis is on students' evaluation of teachers' "curriculum ideology and politics", that is, the performance of teachers in specialized courses reflected from students' eyes.

\section{Acknowledgements}

This research is financially supported by the Research of the Teaching Reform in Universities of Jiangxi Province named "A study on the reform of Ideological and political education in the course of real estate specialty-Taking the course of real estate market analysis as an example" (JXJG-18-2-42), the Youth Planning Fund for Humanities and Social Sciences of Jiangxi education department named "The evolution and management of the functional characteristics of rural housing in northern Jiangxi Province in the 70 years since the founding of new China" (JC19225) and "Youth Marxism Project" of Marxism College in Jiangxi Normal University (2017qmkt012).

\section{Conflicts of Interest}

The authors declare no conflicts of interest regarding the publication of this paper.

\section{References}

Chen, W. B., \& Zhang, Y. C. (2016). Principles of Ideological and Political Education. Beijing: Higher Education Press.

Cheng, G. Y. (2018). Three Focuses on Promoting the Teaching Reform of "Curriculum Ideological Politics”. Guide to Ideological and Theoretical Education, No. 9, 67-70. 
Cheng, G. Y., \& Wang, J. P. (2019). Principles and Concerns of Teachers' "Curriculum Ideological and Political” Performance Evaluation. Ideological and Theoretical Education, No. 1, 79-83.

Commentator of Xinhua News Agency (2016). General Secretary Xi Jinping's Important Speech at the National Conference on Ideological and Political Work in Colleges. Xinhua Net, 2016-12-08.

http://cpc.people.com.cn/xuexi/n1/2016/1209/c385474-28938271.html

He, H. J. (2017). Internal Logic and Construction Strategy of the Development of "Ideological and Political Courses" to "Ideological and Political Courses". Research on Ideological and Political Education, 33, 60-64.

Liu, Z. S., Xie, W. J., Zeng, W. H., \& Fan, Z. G. (2018). Construction and Application of Practical Teaching Platform of "Subject Integration" for Engineering Management Major. Open Journal of Social Sciences, 6, 183-188.

https://doi.org/10.4236/jss.2018.612016

Lu, D. K. (2018). Discussion on Several Core Issues and Solutions in the Implementation of Curriculum Ideological Politics Based on the Discussion on Professional Curriculum Ideological Politics. Ideological and Theoretical Education, No. 3, 64-69.

Mo, F. (2010). Thinking about the Absence of Professional Teachers in the Ideological and Political Education of Universities. Journal of Zunyi Normal College, 12, 94-97.

The Central Committee of the CPC and the State Council (2017). On Strengthening and Improving Ideological and Political Work in Colleges under the New Situation of the opinions. The People's Daily, 2017-02-28.

Xi, J. P. (2016). The Ideological and Political Work through the Education Teaching Process Create a New Situation Our Country Higher Education Enterprise Development. The People's Daily, 2016-12-09.

Xi, J. P. (2017). Xi Jinping on Governance (Volume 2). Beijing: Foreign Languages Press.

Xi, J. P. (2019). Xi Jinping Presided over a Symposium for School Ideological and Political Theory Teachers, Stressing the with Soul and Implement the Party's Education Policy and the Fundamental Task of Building Morality and Cultivating People. People's Daily, 2019-03-19.

Yang, L. P. (2017). Eight Methods of Student-Oriented Ideological and Political Teaching. Chinese Higher Education, No. 18, 30-32.

Yi, X., \& Huang, P. J. (2018). Timely Put Xi Jinping's Thought of Socialism with Chinese Characteristics for a New Era into the Textbook-The Key Textbook of the 96 Horse Projects Was Comprehensively Revised. China Education News, 2018-02-14(01).

Yu, W. J. (1993). Ideology Theory. Shanghai: Shanghai People's Publishing House. 